\title{
Employment Guidance by Ideological and Political Course in Colleges and Universities
}

\author{
Ping Ni \\ Department of telecom engineering, Liaoning railway vocational and technical college, jinzhou, 121000, \\ China
}

305254185@qq.com

Keywords: ideological and political course; guidance; student employment; problem

\begin{abstract}
This paper argues that the employment problem in the thought political lesson teaching activities, the creep cut to undertake to the student employment problems of correct guidance and guidance, to help students establish a correct concept of career, employment, with a positive and healthy attitude to participate in professional competition, will have certain theoretical and practical significance. As an important part of education of universities, ideological and political courses in colleges and universities are theoretical, practical and systematic. In the market economy, the problem of college students' employment difficulty is strengthened with the interaction of ideological and political education. However, high employment expectations, employment information is not clear, lack of inadequate employment preparation, job skills, in large part of the graduates in the still prevalent, seriously affect and hinder the work of employment.
\end{abstract}

\section{Introduction}

The ideological and political course is very important in colleges and universities under the system of higher education. The course is not only confined to theory, but also needs to be combined with practice. At present, the employment rate of graduating students in our country is not optimistic. The ideological and political education should deal with the difficult situation, reducing the anxiety caused by the employment pressure, which is a duty that ideological and political education should do.

\section{Review of Research Status}

The main problems of college students employment, Our country has always attached great importance to the employment of college graduates, and each year the governments try their best to provide more resources to help students to obtain employment. Campus recruitment, online recruitment, special recruitment and other recruitment channels have provided a large number of jobs. However, due to various objective or subjective reasons, the employment of graduates in our country is still serious. The specific issues are listed below.

(1) Low comprehensive quality. With low quality, students can not get the job they want. Of course, this is also related to the educational ability of colleges and universities. The students we educated should have practical ability and good psychological quality.

(2) Backward employment concept and insufficient employment initiative. Views and values of college students have not been successfully converted during school days, so they are relatively passive when looking for a job and don't know how to seize the opportunity, just waiting and being chosen passively. At the same time, their thinking is not flexible. Students are eager to find the job that completely matched with their own professional or interests, and their families always put pressure on them to stay near hometown, so employment region has also been greatly limited.

(3) Employment anxiety comes in advance. College students are not unaware of the employment pressure. A large number of students worry about their employment development too early, and some even begin to worry about their future when they enter college, which is very abnormal. Employment guidance work in colleges and universities of China is not perfect, the simple 
preaching can not help college students know and understand employment or plan their own university development according to their employment expectations. Anxiety caused by the employment pressure can not be a hindrance to college students. Too much anxiety will make college students become too utilitarian, which will affect their correct development. At present, many college students only want to stay in state-owned enterprises or institutions with stable treatment, which is an incorrect employment concept.

(4) Job autonomy is not high .Nowadays graduates after the basic it is 90 students, belong to the one-child generation, there are a lot of students employment was desperate want to go out, but are bound in the parents intend, near employment at home, although it may offer a better job and salary, but in the heart of the parents and children never grow up, always need to take care of, don't want to let the children run away, close to home to find a job better than high salaries work outside.So there are many students underemployed and don't try so hard to find a job, part of the students' choosing a selective is not high, the will is not strong.

\section{Significance and Value of Research}

The importance of ideological and political courses in dealing with employment problem for students. For the problems in the employment guidance of college students, some scholars have pointed out that ideological and political education should not only inherit the traditional methods, but also make innovations to meet the needs of the times. Using modern science and technology, based on network and multimedia technology, teachers should encourage students to take part in career guidance courses and other educational practice activities, and guide them to form a correct view of employment.

(1) The ideological and political course can help students set up a correct outlook on life and values. With the continuous improvement of living standards, the society is full of temptation. It is difficult for college students who have not yet completely entered the society to resist the temptation. Therefore, colleges and universities offer ideological and political courses to help students establish a correct outlook on life, values and world view. The correct views are difficult to form only by professional knowledge, while the ideological and political education course guided by Marx thought could teach students scientific view and methodology.

(2) The ideological and political course can help students stimulate their subjective initiative. We stimulate the students' subjective initiative from two aspects. On the one hand, let the students go out of college. Subjective initiative requires practical action to verify, so the teacher should lead the students to investigate the society, visit the local enterprises and factories, so that students can know more about the society; On the other hand, invite people from all walks of life to speak at school. Each school has a large number of alumni, select representatives of all walks of life to make speeches can help students understand how did the seniors get through this period, which will be a good inspiration for them. Only students know the society and their life correctly can they plan their own life and develop their own future.

(3) Ideological and political classes can improve students' career choice and entrepreneurial autonomy .At present, many college students have weak ability to choose their careers. They are very lazy, lack objective understanding of themselves and correct judgment of social needs, and cannot accurately locate their own strength. Therefore, in ideological and political class teaching, teachers can carry out "career planning and design" activities to determine college students' vocational interests and professional abilities. By conducting "simulated recruitment and interview" activities, we will start to raise students' creative potential and cultivate a good entrepreneurial spirit. Teachers can encourage students to market research, bold, careful cost forecast, and through practice activities, students acquire the ability needed for entrepreneurship and economic conditions, to cultivate entrepreneurial talent to provide the necessary conditions. We should also introduce employment guidance in the timely and appropriate way in the teaching of thought and politics, so that students can set up a correct employment view and lay a solid foundation for future employment. 


\section{Innovation Strategy of Mechanism}

Ideological and political courses penetrate into the employment guidance. For the ideological and political courses offered by the colleges and universities, our survey shows that less than $20 \%$ of the students think it is useless, while the remaining $80 \%$ of students think they can learn from the ideological and political courses. One question in the questionnaire is that what the most important values are for the students, and answers of the vast majority of students are the following three kinds: noble character, great cause, and excellence contribution to the society. From the answer we can see that the ideological and political education has certain effect and guides students establish the correct views. Since the idea of Ideological and political course have a significant impact on students, we should guide students out of employment predicament, build the correct employment expectations, and help students turn anxiety into force. At the same time, let them know what kind of talents the society needs and what qualities they need to avoid unnecessary efforts.

(1) Employment environment. According to the social and economic development in a given period, the employment environment becomes an organic contact network which consists of the state functionaries, colleges and universities, enterprises, college graduates and other factors. It is not a knowledge system, but a theoretical framework, concerning the employment of college students. As a systematic project of educating people, ideological and political education in colleges and universities should flexible and diverse. Based on the characteristics of students of different grades and the systematic arrangement of courses, teachers should carry out education with diversified forms by different stages and levels so as to help students fully aware of their employment environment.

Freshmen do not have much understanding of their major, and there is not much social contact. Therefore, there is no need to talk about too much employment. We can arrange some ideological and political courses so that they can understand the current state development, and social background to and shape their good moral values. When students are sophomore, we should begin to train our students' ideas and ideas carefully. In this process, we should adhere to the "people-oriented" principle, combine the employment guidance with ideological and political course, professional teaching, campus cultural activities and daily management, respect their needs, and guide students to combine personal needs with social needs and find the best balance between them.

(2) Employment concept. One of the primary reasons for the employment problem is the deviation of the students' employment concept, which is one of the problems that ideological and political education should deal with. Nowadays, college students enjoy a rich material life, but also influenced by the society on the impact of various thoughts, which makes a lot of college students' ideological deviation and makes them have an unrealistic idea of their future development. At present, money worship, hedonism and egoism prevail in society, the college students affected by unhealthy temptation begin to evade the correct values and want to take shortcuts when they find job, and thought it was the sign of maturity. Maybe the students who take a shortcut can obtain some false convenience, but when officially entering the society they will find the students who have true skill and genuine knowledge can go far.

(3) The correct method to deal with employment. To solve employment problem, students must have a correct and positive understanding of themselves and take a scientific look at their own employment problems and correctly consider their own employment development. First of all, the students should know themselves well, not only know their advantages and their strengths, but also know shortcomings. objectively recognize my own and correct understanding, but does not represent the pursuit of perfection and excessive criticism, a positive attitude is also very important. Correct understanding don't means the pursuit of perfection and excessive blame, a positive attitude is also very important. Second, good communication skills are very important for employment and career development. Students should build a good relationship with the people around. When you come to employment anxiety, find a friend to confide in and you will be much better.

(4) Carry out ideological education of hard working. Hard working is a necessary path for people to grow up. As an adult entering into society, graduate students will hit the wall everywhere without 
the attitude of hard working. Only hard-working people can have a stable life and realize their personal dream.

(5) Correct understanding of professional counterparts. Professional counterpart is the important reason for employment problem. Many college students have to find job related to their major. In fact, professional counterpart means finding a job matched with their strong point and advantages. Students should correctly understand what they are suitable for, rather than what they have to do. Ma Yun used to be an English teacher, but now he is the most successful businessman in the world.

(6) Have ambitious goals and do every little thing well. The employment goal can not be too unrealistic. Students should know that as a freshman there are lots of things to learn in society. So don't think to be a leader at the beginning, gather experience from ground floor. Only in this way can our development prospects become wider.

\section{Conclusion}

Build a long-term scientific and rigorous employment guidance mechanism to enhance the efficiency of employment guidance work in colleges and universities. College Students' employment guidance is a systemic work. We must explore and sum up experience constantly to build a service work system of college students employment guidance in order to mobilize the enthusiasm of teachers and effectively meet the needs of students' career guidance. The service work system of employment guidance will ensure the full participation, specialization, good experience and theory, various ways and information dynamics. A long-term perfect employment guidance service system is the fundamental measure to improve the employment guidance of college students.

\section{References}

[1] Zhu Jian. The Influence of New Media Era on Ideological and Political education in Colleges and Universities[J]. Education and Vocation, 2016, (20): 96-98.

[2] Lin Jiaquan. Analysis of Disciplinary Education in Ideological and Political Teaching in Colleges and universities[J]. Journal of National Academy of Education Administration, 2016, (20): 96-98

[3] Wang Zhiling. Problems and Countermeasures in the Practice Teaching of Ideological and Political Courses in Colleges and Universities[J]. Education Exploration, 2013, (2): 117-118

[4] Shi Yiman. Research on the Teaching Reform of Ideological and Political Courses in Colleges and Universities under the Background of MOOC[J]. Academic Forum, 2015, 38(9): 177-180

[5] Saren. Research on improving the teaching quality of ideological and political courses in universities [J]. Journal of Inner Mongolia ethnic university, 2011,17(01):124-125.

[6] Liu xiangguang. A brief discussion on the guiding ideology of the exploratory teaching method of ideological and political courses in colleges and universities [J]. Education and occupation, 2010,(05):133-135.

[7] Xue jiu for example, Zhang liyan. In order to guide the reform of ideological and political teaching in colleges and universities by scientific outlook on development [J]. Inner Mongolia electric university journal, 2010,(01):100-101

[8] Chen silian. Exploration of practical teaching mode of ideological and political classroom in universities [J]. Education teaching BBS, 2015,(27):45-46.

[9] zhang yajing. On the reform of college ideological education under the concept of "people-oriented" [J]. Industry and technology BBS, 2013,12(09):173-174. 